\title{
Sub-catastrophic sewage and industrial waste contamination as revealed by marine nematode faunal analysis
}

\author{
P. J. D. Lambshead \\ Department of Zoology, British Museum (Natural History), Cromwell Rd., London SW7 5BD, United Kingdom
}

\begin{abstract}
Studies in benthic biomonitoring have usually concentrated on the macrofauna. In theory the meiofauna possess characteristics which should facilitate their use in a biomonitoring role but unfortunately perceived difficulties in working with meiofaunal taxa have inhibited research into their application in this field. This paper reports an investigation into the effects of contamination at a subcatastrophic level on some marine nematode assemblages of beaches in the Clyde inland sea area, Scotland. Overall abundance and analysis of feeding types revealed localized contamination effects in samples from Ayr Bay compared with reference sites. Stochastic model or simple diversity analyses were not effective. Neutral model and cladistic analyses detected effects in all assemblages exposed to sub-catastrophic contamination.
\end{abstract}

\section{INTRODUCTION}

The potential of marine nematodes for pollution monitoring has been discussed in detail by Ferris \& Ferris 1979, Platt \& Warwick 1980, Coull \& Palmer 1984, and Platt 1984a. The case for nominating nematodes for this role rests on certain of their properties as a taxon. Nematodes are abundant with high species diversity, making them suitable for ecological and statistical analyses. They are ubiquitious and persistent as a taxon and are found in all environmental conditions that can support metazoan organisms. Their small size facilitates sampling and it is possible to take very precise spot samples from the environment using cores. Nematodes have conservative life cycles (i.e. no highly mobile pelagic life stages) so local contamination effects should not be hidden by immigration. They have a rapid turnover compared to the macrofauna and are in intimate contact with pore water. Thus they should demonstrate a fast response to contamination.

Ironically, the conceptual arguments against the use of these organisms for biomonitoring rest on this very property of diversity. This, coupled with chaotic taxonomy, has made the taxon difficult for the nonspecialist. However, recent publications (Lorenzen 1981, Platt \& Warwick 1983) have started to rectify this situation bringing accurate nematode identification within the scope of extension workers.

Biomonitoring at the community level is still given a high priority as indicated at a recent interdisciplinary meeting on marine pollution (Platt 1984b). But most ecotoxicological studies have concentrated on the macrofauna, with a depressing lack of reproducible results. It is still impossible to predict the effects of contamination at levels lower than those causing catastrophic destruction. As Platt et al. (1984) have noted, 'Macrobenthic analysis has so far.failed to provide the answer; it is time to turn the spotlight on the meiofauna'.

This study set out to investigate aspects of the practical potential of marine nematodes as pollution monitoring organisms. To this end nematode assemblages from an anthropogenically contaminated region were compared with assemblages from a relatively uncontaminated geographically close area similar in the major ecological parameters, sediment grain size and salinity (Ferris \& Ferris 1979). A variety of ecological analytical techniques were used in an attempt to detect a pollution effect on the nematode assemblages. This report considers techniques based on overall abundance, feeding types, diversity, stochastic and neutral models, and multi-variate analysis and ecolo- 
gical cladistics. The nematode-copepod ratio was calculated (Raffaelli \& Mason 1981) but rejected as a reliable indicator of contamination, as reported elsewhere (Lambshead 1984). This paper will concentrate on the nematode assemblages.

\section{MATERIALS AND METHODS}

Study area. The inland sea area of the Firth of Clyde was chosen for the study. This estuary offered a number of advantages for the analysis of pollution effects on marine nematode assemblages. Highly contaminated regions were found in close proximity to relatively uncontaminated regions which were similar in important ecological parameters. Sediments in these regions consisted of fine sand rather than the muddy sediments more often associated with pollution. Nematode assemblages in sand have a higher diversity than mud assemblages (Ferris \& Ferris 1979) facilitating the detection of pollution-induced changes. The contaminated Ayrshire coast had already been the subject of an extensive nematode survey by Jayasree (1976). Sediments in these regions were similar to those in relatively near, uncontaminated areas whose nematode assemblages have been previously reported on: Strangford Lough, Northern Ireland (Platt 1971, $1977 \mathrm{a}, 1977 \mathrm{~b})$ and Loch Ewe, west coast of Scotland (McIntyre et al. 1970, Zhang unpubl.).

An initial survey was used to screen likely reference stations to ensure that they had similar sediments to putative contaminated stations. The Clyde estuary is rather unusual in that reference and contaminated sites with similar sediment characteristics can be found in close proximity.

The main potential disadvantage of the Firth of Clyde for this study is that it is an estuary and so may be subject to salinity fluctuation. Such variations are undesirable as they could mask possible effects of contamination. However, Johnston et al. (1974) described the Clyde as 'not a typical estuary' which 'in many respects can be regarded as a shallow sea'. They reported that salinity varies only gradually and that the salinity at $3 \mathrm{~m}$ ranged from about $31.5 \%$ at the mouth of the River Clyde to $33.7 \%$ near the Mull of Kintyre. Much of the Firth had salinities in the range $33.2 \%$ to $33.5 \%$ and zonation as a result of salinity is only likely to occur in salinities ranging from $3 \%$ to $30 \%$ (Ferris \& Ferris 1979).

The sources and scale of waste disposal in the Firth are extensively covered in the Clyde River Purification Board's (1976) internal report 'Water Quality, A Baseline Report'. There are 3 main sources of contamination in the inland sea area of the Clyde. Large quantities of domestic, industrial and agricultural waste are washed into the area by the River Clyde. Activated sludge and industrial waste is dumped in the Firth south of Garroch Head, Isle of Bute, in enormous quantities of around 1,000,000 tons per year. Sewage and industrial waste is disposed of through effluent pipes off the Ayrshire coast, particularly Irvine Bay, and into the Garnock/Irvine estuary. In addition the Firth suffers from oil contamination from both normal shipping and tankers using the Loch Long terminal in the upper Firth.

Sampling stations. Six sampling stations (numbered 1 to 6) were chosen, 3 in heavily contaminated areas and 3 in areas thought to be free from direct contamination (Fig. 1). Stations were set at extreme low water mark, defined by sampling at the water line at low tide as given in Admiralty Tide Tables (1978). Samples were taken in this part of the beach to minimise natural disturbance (Platt 1977a) which might otherwise tend to mask a potential pollution effect. All the stations were sampled on 16 and 17 September 1978. A single set of samples were taken within this short period of time to avoid seasonal effects

Three reference stations (1 to 3 ) were located on the west coast of the Isle of Bute. This area is relatively sparsely inhabited with little industry and hence minimal contamination. However, the dumping ground off Garroch Head is only $3 \mathrm{~km}$ south of the island and

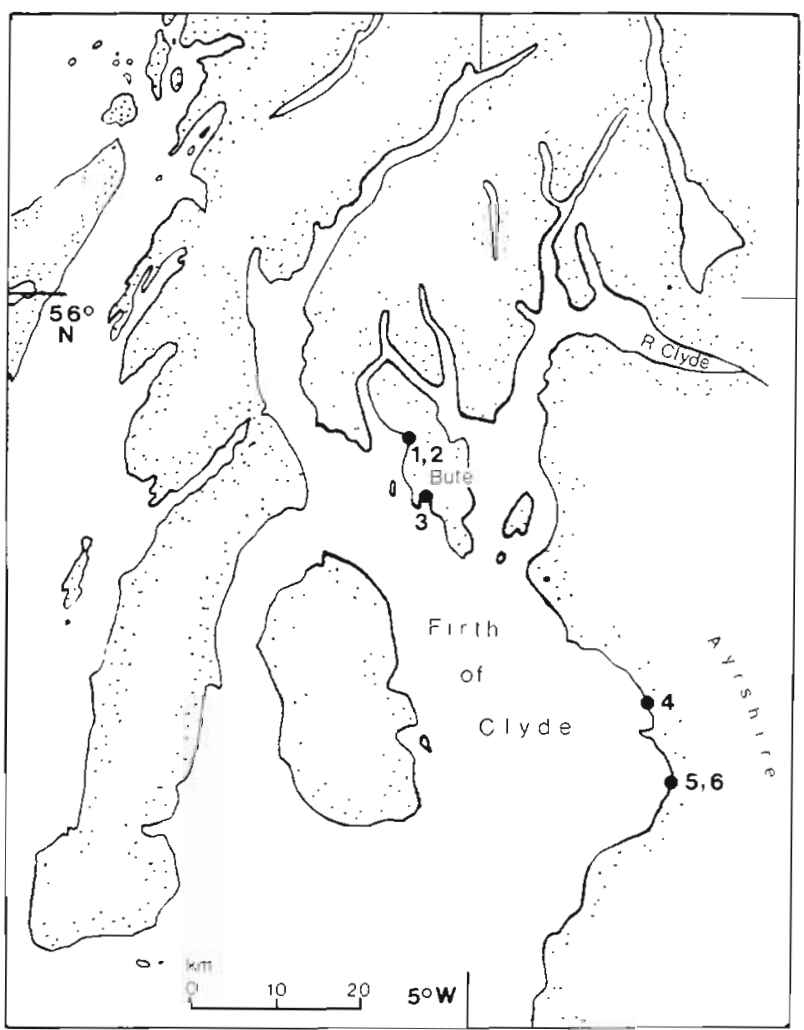

Fig. 1. Map of the Firth of Clyde inland sea area showing the locations of Stn 1 to 6 
Mackay \& Topping (1970) demonstrated with sea bed drifters that benthic currents could conceivably carry contaminants as far north as the island of North Bute (between Stn 2 and Stn 3). In the same paper the authors noted that although there was some build-up of metal waste in the dumping area, carbon analysis indicated that the sludge was either spread very thinly over the ground or the carbon content was quickly assimilated by organisms. Further work by Mackay et al. (1972), Topping \& McIntyre (1972), and Halcrow et al. $(1973,1974)$ suggested that the effects of sludge dumping were localized. So there is no reason to believe that the reference stations might have been contaminated from this source.

Stn 1 and 2 were sited in the north and south part of Ettrick Bay respectively, about $1 \mathrm{~km}$ apart. Stn 3 was located on the western half of Scalpsie Bay.

Three contaminated stations ( 4 to 6 ) were located on the Ayrshire coast on the east side of the sea area. Stn 4 was sited in the southern part of Irvine Bay. This is a popular tourist area and 15 pipes release sewage and some industrial waste into the bay; in addition there are 3 pipes disposing of industrial effluent. Some of these pipes terminate above the low water mark. Much of the sewage is untreated and the industrial effluents are a complex cocktail including heavy metals, notably copper, and nutrients. The Clyde River Purification Board (1976) quoted the BOD (biological oxygen demand, i.e. the amount of oxygen required to degrade organic material and oxidise reduced substances in a water sample) of the various effluents as 28,660 tonnes $\mathrm{yr}^{-1}$.

Stn 5 and 6 were sited in Ayr Bay. This has a lower effluent load than Irvine Bay with a BOD of about 3,800 tonnes $\mathrm{yr}^{-1}$. Seven short pipes dispose of sewage and industrial waste into the bay, the sewage receiving only preliminary if any treatment before disposal. Stn 5 was positioned close to a domestic sewage/stormwater pipe. One core (5A) was taken from the terminus of the pipe. Since it seemed possible that this core, or to some extent all of Stn 5, might be unduly influenced by localized heavy contamination another station, Stn 6, was sited approximately $30 \mathrm{~m}$ to the south.

Four core-samples (A to D) were taken at each station using a $22 \mathrm{~mm}$ diameter hand-held corer. One (D) was used for grain size analysis, the remaining 3 being used for biological samples 3 represents an optimum balance between the time taken to process the samples and statistical accuracy; Platt 1977b). Samples A to C were sectioned at roughly $5 \mathrm{~cm}$ intervals and fixed in the field with generous applications of $4 \%$ formalin in seawater.

All the biological samples (except Cores $3 \mathrm{~A}$ and 4A) were subsampled using a sample-splitter. Nematodes were extracted by decantation through a $35 \mu \mathrm{m}$ filter and the efficiency checked as recommended by Platt $\&$ Warwick (1983). Sediment grain sizes were analysed according to the dry-sieve method devised by Morgans (1956), using 1,000, 710, 500,355, 250, 180, 125, 90 \& $63 \mu \mathrm{m}$ sieves. Subsieve analysis was unnecessary as less than $1 \%$ of the samples passed through the $63 \mu \mathrm{m}$ sieve (Morgans 1956).

\section{RESULTS AND DISCUSSION}

\section{Physical component}

Grain size analysis

Cumulative grain size curves demonstrated that the sediments were well sorted with regular distributions, the parameters of which are shown in Table 1. It should be noted that the stations displayed closely similar sediment characteristics, with the exception of

Table 1. Sediment grain size analysis. QD (quartile deviation) and Skq (skewness) indicate the degree of sorting of the sediments (after Morgans 1956)

\begin{tabular}{cccc|}
\hline Station & Median $(\mu \mathrm{m})$ & QD $(\mu \mathrm{m})$ & Skq $(\mu \mathrm{m})$ \\
\hline 1 & 157 & 20 & -2 \\
2 & 190 & 34 & -1 \\
3 & 265 & 79 & +28 \\
4 & 139 & 22 & -1 \\
5 & 147 & 17 & 0 \\
6 & 145 & 18 & +2 \\
\hline
\end{tabular}

Stn 3 which was coarser and less well sorted in contrast to the results suggested by the initial survey for this station. As Stn 3 was clearly anomalous only 1 core from this station was worked up.

\section{Biological component}

From the 16 cores, 9,775 specimens were recovered and all but $300(3 \%)$ were separated into 113 distinct species; of these 73 were identified down to the specific level (65\%), 10 appeared to be new to science ( $9 \%$ ), 28 were determined to generic level ( $25 \%$ ), and 2 to family level $(2 \%)$.

\section{Nematode densities}

Nematode densities at the 6 stations are shown in Table 2 . The contaminated stations (4 to 6 ) do have a significantly lower mean density than the reference 
Table 2. Density of nematodes in Clyde samples

\begin{tabular}{|c|c|c|}
\hline Station/core & $\begin{array}{l}\text { Nos. of } \\
\text { rdividuals }\end{array}$ & $\begin{array}{c}\text { Density } \\
\text { per } 10 \mathrm{~cm}^{2}\end{array}$ \\
\hline $1 \mathrm{~A}$ & 515 & 5,417 \\
\hline $1 \mathrm{~B}$ & 570 & 5,995 \\
\hline $1 C$ & 971 & 10,213 \\
\hline $2 \mathrm{~A}$ & 479 & 5,038 \\
\hline $2 \mathrm{~B}$ & 455 & 4,786 \\
\hline $2 \mathrm{C}$ & 606 & 6,374 \\
\hline 3 & $1,476^{\circ}$ & 3,881 \\
\hline $4 \mathrm{~A}$ & $2,405^{\circ}$ & 6,324 \\
\hline $4 \mathrm{~B}$ & 608 & 6,395 \\
\hline $4 C$ & 616 & 6,479 \\
\hline $5 \mathrm{~A}$ & 51 & 536 \\
\hline $5 \mathrm{~B}$ & 175 & 1.841 \\
\hline $5 \mathrm{C}$ & 175 & 1,841 \\
\hline $6 \mathrm{~A}$ & 232 & 2,440 \\
\hline $6 \mathrm{~B}$ & 152 & 1,559 \\
\hline $6 \mathrm{C}$ & 269 & 2,829 \\
\hline \multicolumn{3}{|c|}{$\begin{array}{l}\text { - Cores with their total number of individuals counted, } \\
\text { rather than a } 25 \% \text { subsample }\end{array}$} \\
\hline
\end{tabular}

stations ( 1 to 3 ), $5 \%>p>2 \%$ (Student's $t$ test assuming unequal variances). However, contaminated Stn 4 alone (Irvine Bay) is significantly different from Stn 5 and 6 (Ayr Bay), $0.1 \%>p$, but not from the reference stations, $\mathrm{p}>25 \%$ ( $t$ test). The Ayr Bay stations therefore exhibit a significantly lower nematode density than the other stations.

Core 5A was taken from within $1 \mathrm{~m}$ of the end of the effluent pipe in Ayr Bay. The nematode density of this core was 3.1 standard deviations lower than the mean of the other 5 cores from Ayr Bay. The results from contaminated Irvine Bay show that nematode densities in the assemblages examined were unaffected by the non-catastrophic levels of contamination. The reduced densities at Ayr Bay, especially the core taken from the terminus of the effluent pipe, would seem to be due to a localized contamination.

Table 3. Nematode densities, organic carbon levels and median sand grain size for 6 stations at low water locations in Irvine Bay (Jayasree 1976)

\begin{tabular}{|rrrr|}
\hline Station & $\begin{array}{c}\text { Nematodes } \\
\text { per } 10 \mathrm{~cm}^{2}\end{array}$ & $\begin{array}{c}\text { Organic } \\
\text { carbon } \\
\left(\mu \mathrm{g} \mathrm{C} \mathrm{g}{ }^{-1} \text { sand }\right)\end{array}$ & $\begin{array}{c}\text { Median } \\
\text { grain size } \\
(\mu \mathrm{m})\end{array}$ \\
\hline I & 8,677 & 1,149 & 158 \\
II & 9,495 & 739 & 142 \\
III & 988 & 777 & 186 \\
IV & 14,053 & 1,032 & 160 \\
V & 48,827 & 1,175 & 140 \\
VI & 12,665 & 1,158 & 138 \\
\hline
\end{tabular}

Previous work has noted changes in nematode densities with contamination ranging from increases (McIntyre 1977. McLachlan et al. 1977) to catastrophic declines (Wormald 1976, Giere 1979, Boucher 1980) so clearly dose-response effects on overall abundances are complicated.

From these results it might be tempting to suggest that nematode densities could be indicative of localized contamination but comparison with published data immediately reveals certain difficulties. For example, Table 3 shows nematode densities, collected using similar techniques to those employed here, from 6 stations in Irvine Bay in August 1974 (Jayasree 1976). The range of variation was rather large $(50 \times)$ and cannot be satisfactorily associated with contamination; the correlation between nematode densities and organic carbon content was $+0.54 \mathrm{com}$ pared to -0.55 for sediment grain size.

\section{Feeding types}

The concept of nematode feeding types was devised by Wieser (1953) who suggested 4 groups based on the morphology of the buccal cavity. Initially the groups were linked to suggested feeding strategies but it is probably safer to regard them solely as morphological types whose relative abundances reflect to some degree ecological parameters. This simple concept has stood the test of time and has been found a valuable tool by a number of authors (e.g. King 1962, Hopper \& Meyers 1967, Tietjen 1969, Ferris \& Ferris 1979, Platt \& Warwick 1980, Kito 1984).

The 4 feeding types are $1 \mathrm{~A}$ - buccal cavity absent or minute, no teeth; $1 B$ - conical or cup-shaped buccal cavity, teeth absent or minute; $2 A$ - medium sized buccal cavity, small to medium teeth; $2 B$-large buccal cavity, large teeth or other well-developed cuticularized structures. It should be noted that there is not complete agreement as to which species belongs to which feeding category. The system used here is recorded in the species list (see 'Appendix'). Generally it follows the same system used by Platt (1971) and Jayasree (1976). Platt (1971) is followed in including Spirinia in the $1 \mathrm{~A}$ category rather than the $2 A$ and Jayasree (1976) is followed in including Metachromadora in $2 A$ rather than $2 B$. Where other authors are quoted their data have been revised to ensure comparability with the system used here.

The percentage abundances of the 4 feeding types in the cores are shown in Table 4 . Stn 1 to 4 were dominated by $2 A$ and $1 A$ nematodes. However, while the $2 A$ group was still an important component of Stn 5 and 6 , the $1 B$ group was the second major component, indeed the dominant group in the core $(5 \mathrm{~A})$ closest to 
the effluent pipe. In the specific sediments studied it would appear that the $2 \mathrm{~A}$ group are a constant factor but that contamination is associated with a relative increase in the $1 B$ group. This can be conveniently expressed as a $1 B / 2 A$ ratio (Table 4 ). The mean of this ratio for the Ayr Bay stations is significantly different from the mean of the ratio of the other stations using Student's $t$ test $(1 \%>\mathrm{p}>0.2 \%)$.

Table 5 shows percentage abundances of feeding types for published data from projects which have used similar collecting techniques to those employed here. The first 4 samples are all from low water/sublittoral fine sandy sediments of the Scottish west coast and so are directly comparable with the Clyde samples studied here. The distribution of feeding types shows marked similarity to Table 4 , with $1 B / 2 A$ ratios of less

Table 4 . The percentage abundances of the 4 nematode feeding types for each of the core samples and for the amalgamated data for each station

\begin{tabular}{|lrrrrr|}
\hline $\begin{array}{l}\text { Station/ } \\
\text { Core }\end{array}$ & $1 A$ & $1 B$ & $2 A$ & $2 B$ & $\begin{array}{c}1 B / 2 A \\
\text { ratio }\end{array}$ \\
\hline 1A-C & 28 & 13 & 57 & 2 & 0.23 \\
$1 \mathrm{~A}$ & 28 & 17 & 52 & 2 & 0.33 \\
$1 \mathrm{~B}$ & 20 & 12 & 65 & 3 & 0.18 \\
$1 \mathrm{C}$ & 36 & 9 & 54 & 2 & 0.17 \\
$2 \mathrm{~A}-\mathrm{C}$ & 49 & 7 & 41 & 3 & 0.17 \\
$2 \mathrm{~A}$ & 51 & 4 & 43 & 2 & 0.09 \\
$2 \mathrm{~B}$ & 49 & 10 & 36 & 6 & 0.28 \\
$2 \mathrm{C}$ & 46 & 7 & 45 & 2 & 0.16 \\
3 & 9 & 15 & 73 & 3 & 0.20 \\
$4 \mathrm{~A}-\mathrm{C}$ & 36 & 8 & 52 & 3 & 0.15 \\
$4 \mathrm{~A}$ & 24 & 10 & 61 & 5 & 0.16 \\
$4 \mathrm{~B}$ & 33 & 4 & 59 & 4 & 0.07 \\
$4 \mathrm{C}$ & 52 & 9 & 37 & 1 & 0.24 \\
$5 \mathrm{~A}-\mathrm{C}$ & 10 & 50 & 36 & 4 & 1.39 \\
$5 \mathrm{~A}$ & 6 & 62 & 26 & 6 & 2.38 \\
$5 \mathrm{~B}$ & 6 & 41 & 49 & 4 & 0.84 \\
$5 \mathrm{C}$ & 18 & 48 & 33 & 1 & 1.45 \\
$6 \mathrm{~A}-\mathrm{C}$ & 19 & 38 & 40 & 3 & 0.95 \\
$6 \mathrm{~A}$ & 17 & 39 & 41 & 3 & 0.95 \\
$6 \mathrm{~B}$ & 12 & 46 & 39 & 3 & 1.18 \\
$6 \mathrm{C}$ & 28 & 28 & 41 & 3 & 0.68 \\
& & & & & \\
\hline
\end{tabular}

than 0.5. The Lynher Estuary sample differs in 2 respects; it was taken from a midtide station on a mudbank. The $1 B / 2 A$ ratio is distinctly higher at 0.7 , closer to the Ayr Bay stations which have a mean of 1.17. It may be speculated that the contamination at Stn 5 and 6 had the effect of producing an assemblage more typical of muddy or more disturbed sediments.

There is some evidence in the literature to support this speculation. Heip \& Decraemer (1974) identified 2 allegedly contaminant-disturbed stations by means of diversity analysis. Their nematode assemblages were dominated by Sabatieria and Theristus. The authors ascribed this domination to the fact that these genera may be 'generalists'; they are also $1 B$ feeding types.

Tietjen (1980) used cluster analysis to divide New York Bight stations into 2 groups, conforming roughly to a sand group and a fine and silty sand group. However, there were 2 anomalous sand stations which clustered with the silty sand group. The anomalous stations showed higher levels of contamination (as measured by organic carbon and metal concentration) than the other sand stations. Tietjen noted that the sand group was characterized by Chromadoridae (2A), Desmodoridae (2A), Pomponema tautraense (2A), Monoposthia duodecimalata (2A), Xyala striata (1B) and Theristus problematicus (1B), with only 1 species of Comesomatidae (1B). In contrast the silty sand/ contaminated group was characterized by Comesomatidae (1B), Terschellingia longicaudata (1A), Tripyloides gracilis (1B) and Odontophora armata (2A). In this group he noted an absence of Monoposthiidae (2A) and low abundances of Chromadoridae (2A) and Desmodoridae ( $2 A)$. In other words the 2 anomalous stations shared 2 characteristics with the silty sand stations: (a) contamination and (b) a proportional reduction in the $2 A$ feeding type compared to the $1 B$.

It may therefore be concluded that in this type of habitat contamination has the effect of altering the proportional abundance of feeding types in the assemblage from a structure characteristic of a sandy community to one characteristic of a mud or silty sand community. This may be generally true but it would be naive to assume that the ratios obtained in this study

Table 5. The percentage abundances of the 4 nematode feeding types for various British shallow sublittoral, low and mid-water stations

\begin{tabular}{|c|c|c|c|c|c|c|}
\hline \multirow[t]{2}{*}{ Station } & \multicolumn{4}{|c|}{ Feeding types } & \multirow{2}{*}{$\begin{array}{c}1 B / 2 A \\
\text { ratio }\end{array}$} & \multirow[t]{2}{*}{ Source } \\
\hline & $1 A$ & $1 B$ & $2 A$ & $2 B$ & & \\
\hline Oct sample from low water stn, N. Irvine Bay, Clyde & 11 & 22 & 62 & 5 & 0.35 & Jayasree 1976 \\
\hline Jul sample from low water stn, Firemore Bay, Loch Ewe & 11 & 20 & 56 & 3 & 0.36 & McIntyre et al. 1970 \\
\hline Oct sample from sublittoral stn, Firemore Bay, Loch Ewe & 28 & 10 & 50 & 12 & 0.20 & Zhang unpubl. \\
\hline Sep sample from low water stn, Strangford Lough & 12 & 26 & 55 & 7 & 0.47 & Platt 1971 \\
\hline Oct sample from mid-water stn, Lynher Estuary & 26 & 30 & 43 & 1 & 0.70 & Warwick \& Price 1979 \\
\hline
\end{tabular}




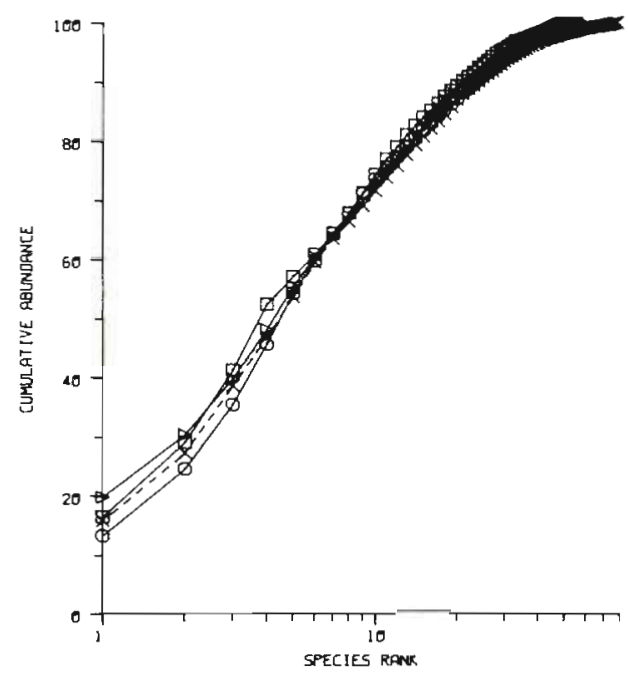

Fig. 2. $k$-dominance curves for nematode assemblages from Stn 1. $(\square-\square)$ Core $A_{;}(O-O)$ Core $B_{i}(\Delta-\Delta)$ Core $C_{i}(\times-.-\times)$ combined cores

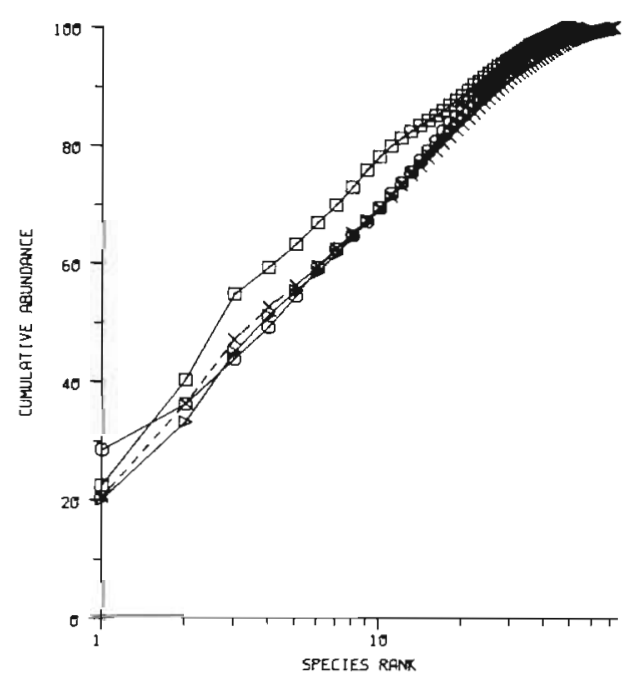

Fig. 3. Stn 2, legend as for Fig. 2

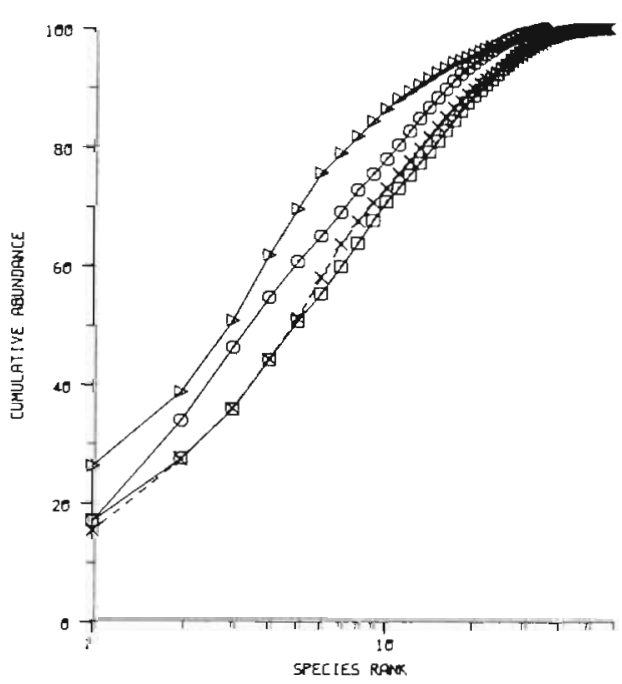

Fig. 4. Stn 4, legend as for Fig. 2

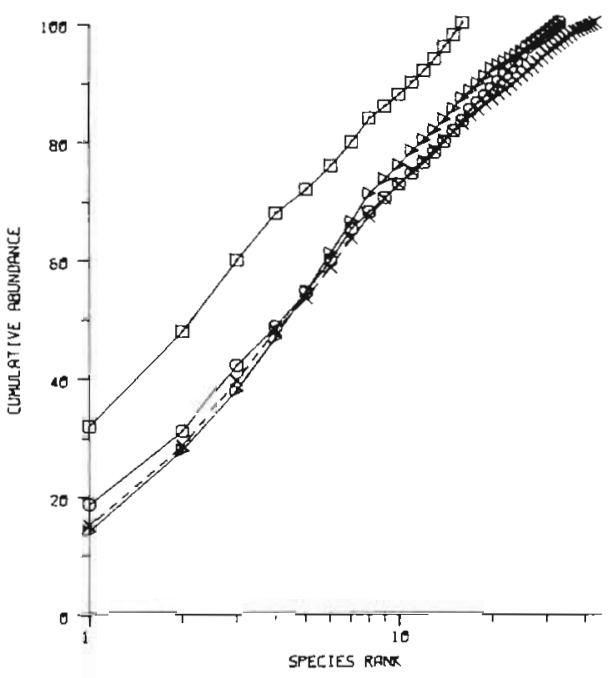

Fig. 5. Stn 5, legend as for Fig. 2

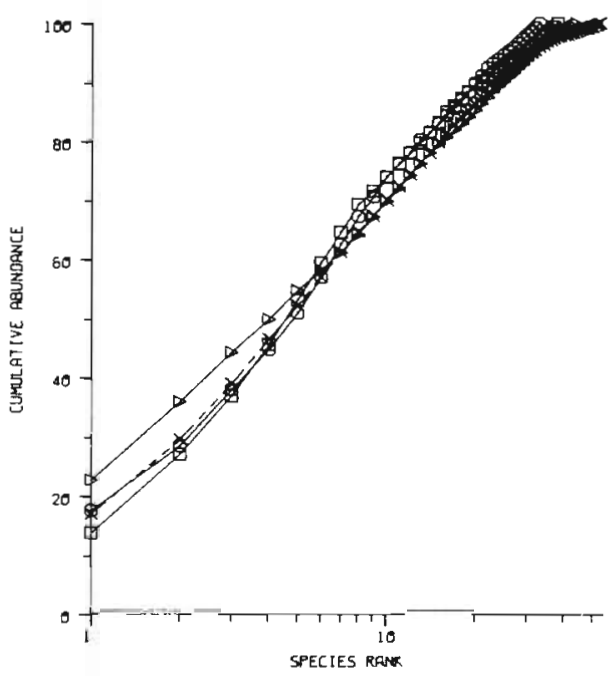

Fig. 6. Stn 6, legend as for Fig. 2

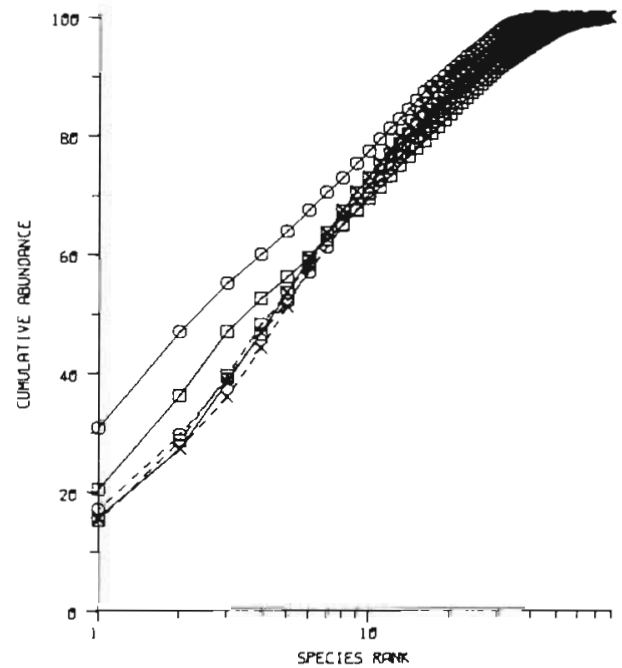

Fig. 7. $k$-dominance curves for amalgamated data from $S \operatorname{Stn} 1$, $2,4,5$ and 6 and the single core from $\operatorname{Stn} 3$. Reference stations (solid line): $(x) \operatorname{Stn} 1 ;(\square) \operatorname{Stn} 2 ;(O) \operatorname{Stn} 3$. Contaminated stations (dashed line): $(\times) \operatorname{Stn} 4$; (ᄆ) Stn $5 ;(0) \operatorname{Stn} 6$ 
Table 6. Percentage abundances of the 4 nematode feeding types for the Exe Estuary (Warwick 1971)

\begin{tabular}{|c|c|c|c|c|c|}
\hline \multirow[t]{2}{*}{ Sediment type } & \multicolumn{4}{|c|}{ Feeding types } & \multirow{2}{*}{$\begin{array}{c}1 B / 2 A \\
\text { ratio }\end{array}$} \\
\hline & $1 A$ & $1 B$ & $2 A$ & $2 B$ & \\
\hline Mud & 20 & 35 & 25 & 20 & 1.40 \\
\hline Muddy sand & 5 & 48 & 24 & 24 & 2.00 \\
\hline Fine sand & 10 & 29 & 14 & 48 & 2.07 \\
\hline Well-drained sand & 10 & 14 & 48 & 29 & 0.29 \\
\hline $\begin{array}{l}\text { Coarse sand (with } \\
\text { water table) }\end{array}$ & 5 & 26 & 35 & 35 & 0.74 \\
\hline
\end{tabular}

are of any value except for comparing contaminated and reference stations from within the same habitat. For example, Table 6 shows feeding type abundances for various uncontaminated sediments in the Exe Estuary (Warwick 1971). As predicted, the $1 B / 2 A$ ratio decreases from muddy to coarse sand. However, in this location, unlike the Clyde, fine sand was similar to silty sand and in general the ratios were larger.

\section{Diversity}

The diversity of the nematode assemblages was examined using $k$-dominance curves (Lambshead et al. 1983). Fig. 2 to 6 show the $k$-dominance curves for Stn $1,2,4,5$ and 6 , respectively. The solid lines show the diversity of each core while the dotted lines show the diversity of the amalgamated data from the 3 cores taken at each station.

Stn 1, 2 and 6 showed close similarity in the diversity of the replicates. There was some variation in the diversity of the contaminated Irvine Bay cores, Stn 4. Stn 5 exhibited a sharp discontinuity between Core $5 \mathrm{~A}$ and Cores $5 \mathrm{~B}$ and $5 \mathrm{C}$. There was a marked reduction in the diversity of the $5 \mathrm{~A}$ sample which was taken from the terminus of the effluent pipe.

Fig. 7 shows the comparison between $k$-dominance curves for the single core from Stn 3 and the amalgamated data from the other 5 stations. Clearly there is no distinction between the diversities of the contaminated and the uncontaminated stations. Stn 3 shows a slightly lower diversity than the others. The amalgamated data from Stn 1 is therefore used as representative of these Clyde stations to compare diversities with relevant published work.

Fig. 8 shows $k$-dominance curves of nematode assemblages from an uncontaminated low water station in Strangford Lough (Platt 1971), median grain size 190 to $200 \mu \mathrm{m}$, compared with Stn 1. The diversities are near identical. Fig. 9 shows a similar comparison with assemblages in uncontaminated Firemore Bay, a low water station of median grain size 178 to
$200 \mu \mathrm{m}$ (McIntyre et al. 1970) and a shallow sublittoral station of median grain size 190 to $200 \mu \mathrm{m}$. The Firemore Bay stations show a range of diversity. Stn 1 lies midway between the sublittoral and low water July samples. These diversity comparisons with uncontaminated samples show no evidence that the Clyde assemblages sampled were affected by contamination.

\section{Stochastic models}

Stochastic models, such as the log-normal, are not utilized here for the detection of the effects of contami-

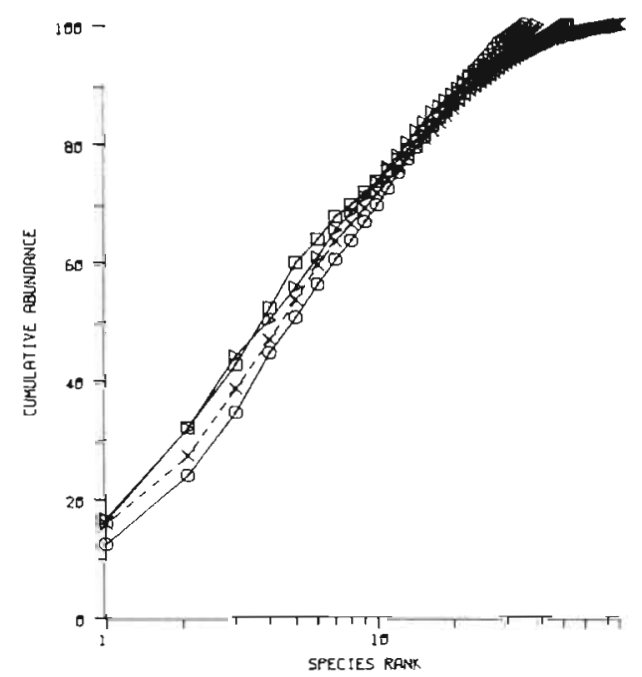

Fig. 8. $k$-dominance curves for nematode assemblages from Stn 1, Clyde inland sea area and Stn C (low water), Strangford Lough, Northern Ireland (after Platt 1971). (X ... X) Stn 1 , Cores A to C. Stn C: () Jul; (O) Sep; $(\Delta)$ Nov

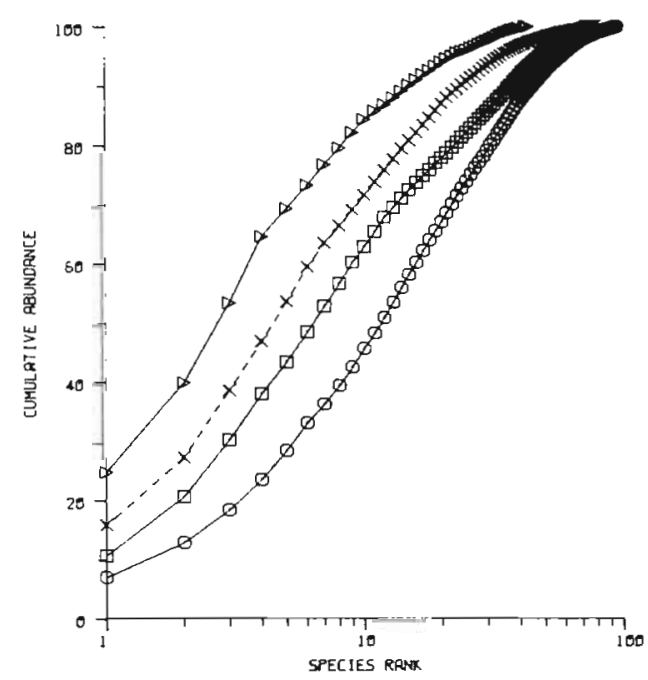

Fig. 9. $k$-dominance curves for nematode assemblages from Stn 1, Clyde inland sea area, a sublittoral station (after Zhang unpubl.) and a low water station (after McIntyre et al. 1970) in Firemore Bay, Scotland. $(\times-. \times)$ Stn 1, Cores A to C. Sublittoral station: ( $\square$ ) Jul; (O) Oct. $(\triangle)$ Low water station, Jul 
nation on the Clyde nematode assemblages for reasons which are discussed in detail elsewhere (Lambshead \& Platt 1985, Platt \& Lambshead 1985), including an examination of the data from this study.

\section{Neutral model analysis}

The diversity curves appeared to demonstrate that Core $5 \mathrm{~A}$ had a reduced diversity, presumably due to a localized contamination effect from the effluent pipe. All diversity analyses are to some degree sample-size dependent. This is because diversity includes some measure of species richness and species richness is to some degree proportional to the number of individuals. This effect is most pronounced with small samples. Because a species can never be represented by less than 1 individual, as sample size decreases some rare species will be lost. Core $5 \mathrm{~A}$ had a significantly lower number of individuals than the other Ayr Bay cores. It also had a low number of species (Table 7). It may be

Table 7 . Number of identified individuals $(N)$, species $(S)$, simple dominance (d) and neutral model $V$ statistic for each core

\begin{tabular}{|crrrr|}
\hline Station/core & $\mathrm{N}$ & $\mathrm{S}$ & $\mathrm{d}$ & $\mathrm{V}$ \\
\hline $1 \mathrm{~A}$ & 508 & 49 & 17 & -1.05 \\
$1 \mathrm{~B}$ & 549 & 56 & 13 & -1.28 \\
$1 \mathrm{C}$ & 950 & 56 & 20 & -0.65 \\
$2 \mathrm{~A}$ & 464 & 49 & 22 & -2.45 \\
$2 \mathrm{~B}$ & 425 & 47 & 28 & -1.00 \\
$2 \mathrm{C}$ & 578 & 57 & 20 & -1.42 \\
$3^{\circ}$ & 1415 & 44 & 31 & -0.52 \\
$4 \mathrm{~A}$ & 2325 & 50 & 17 & +1.30 \\
$4 \mathrm{~B}$ & 600 & 35 & 17 & +0.59 \\
$4 \mathrm{C}$ & 609 & 36 & 26 & -1.41 \\
$5 \mathrm{~A}$ & 50 & 16 & 32 & -1.15 \\
$5 \mathrm{~B}$ & 170 & 33 & 19 & -0.08 \\
$5 \mathrm{C}$ & 168 & 33 & 14 & -0.23 \\
$6 \mathrm{~A}$ & 231 & 38 & 15 & -0.38 \\
$6 \mathrm{~B}$ & 147 & 32 & 18 & -0.08 \\
$6 \mathrm{C}$ & 266 & 43 & 23 & -1.22 \\
Cores with their total number of individuals determined. \\
rather than a 25\% subsample \\
\hline
\end{tabular}

therefore that the lower diversity exhibited by this core is an artifact of a smaller sample. It would still be an artifact even if the low density was a genuine reflection of a contamination effect.

One way to avoid the sample size problem is to concentrate on the evenness component of diversity which is far less susceptible to sample size effects. The simplest way to measure evenness is by calculating simple dominance, i.e. the percentage of the sample dominated by the commonest species (Shaw et al.

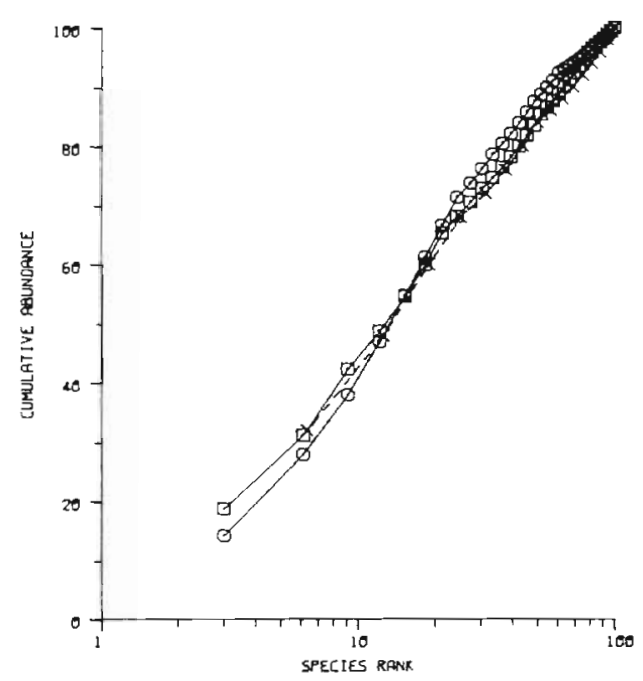

Fig. 10. Lorenz equitability curves for nematode assemblages from Stn 5. $(\times \ldots \times)$ Core $A_{i}(\square)$ Core $B_{;}(0)$ Core C

1983). Core $5 \mathrm{~A}$ had a simple dominance index which, although higher than the other Ayr Bay cores (Table 7), was no higher than uncontaminated Stn 3. A more sophisticated method for measuring evenness is the Lorenz curve derived from a $k$-dominance curve (Lambshead et al. 1983). The Lorenz curves for Stn 5 (Fig. 10) indicate that Core 5A has an equitability curve indistinguishable from $5 \mathrm{~B}$ or $5 \mathrm{C}$. These results suggest that the low diversity measured for Core 5A is an artifact.

An extremely sensitive, and relatively sample-size independent, method for analysing diversity was developed by Caswell (1976) from a neutral model for genetic studies devised by Ewens (1972). This model generates a species distribution for a sample of given number of individuals and species assuming no interspecific biotic interactions or differential responses to the environment (i.e. no species has any competitive advantage over other species and species do not interact). A theoretical diversity $\left(\mathrm{EH}^{\prime}\right)$ is produced from this distribution. A deviation statistic $\mathrm{V}$ is calculated by subtracting $E H^{\prime}$ from the actual diversity of the sample $\left(\mathrm{H}^{\prime}\right)$ and dividing by the standard deviation of $\mathrm{EH}^{\prime}$. The use of the neutral model to analyse patterns of marine benthic species diversity and its implications for the relationship between disturbance and diversity is discussed by Platt \& Lambshead (1985).

Table 7 shows the $\mathrm{V}$ statistics for the Clyde samples. $V$ was negative in all but 2 cases. This is not unusual for benthic data, positive V's being characteristic of post-catastrophe situations (Lambshead \& Platt 1985, Platt \& Lambshead 1985). The reference cores had a mean $V$ of -1.20 compared to a mean of -0.30 for the contaminated cores. The means were significantly different $(0.05 \%>p$ using a $t$ test) indicating that the 
contaminated cores had a significantly higher diversity than the reference cores. The $\mathrm{V}$ statistic for Core $5 \mathrm{~A}$ was not particularly low; 5 of the other 15 cores had lower diversities.

\section{Ordination}

Five principal coordinates analyses were made of the data: Gower's index with joint absences included; joint absences excluded; reruns of these with data rescaled into 5 logarithmic abundance classes; and the Bray-Curtis index of similarity.

Fig. 11 shows a plot of Vectors I and II of the principal coordination analysis using Gower's index with joint absences included. As all the principal coordination runs using Gower's index produced similar results this plot will be quoted as representative of them all.

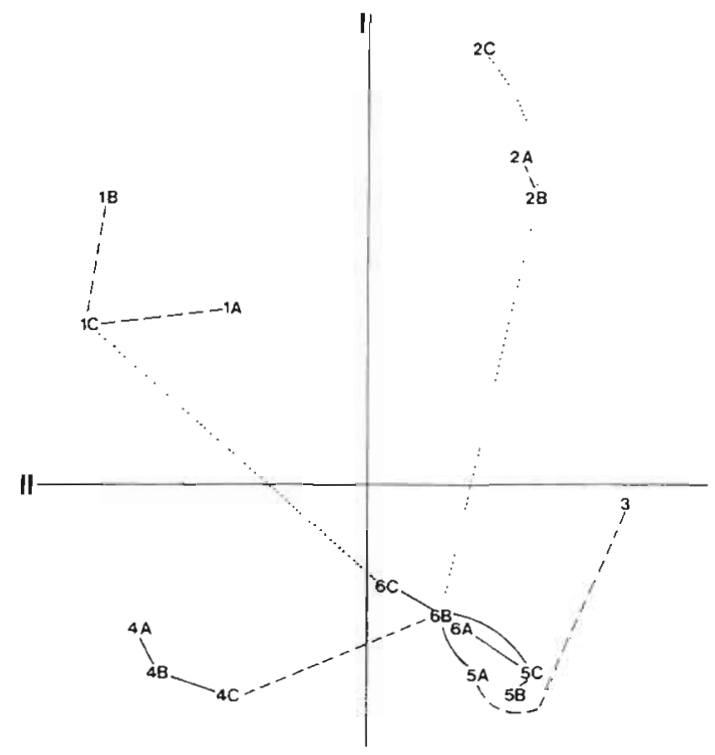

Fig. 11. Principal coordinate analysis of cores using Gower's similarity coefficient with joint absences included; y axis = Vector $\mathrm{I}, \mathrm{x}$ axis $=$ Vector II. The minimum spanning tree (MST) is overlaid, dotted line indicates similarity of 74 to $76 \%$, dashed line 76 to $84 \%$ and unbroken line 85 to $89 \%$

The minimum spanning tree was imposed over the plot. Examination of the eigenvalues, which give the proportion of the total variance accounted for by each axis, indicated that only $20 \%$ of the variation was incorporated in the first vector. Five groups can be distinguished splitting the stations up geographically. Stn 5 and 6 which were only $30 \mathrm{~m}$ apart form a single group. Vector III conveyed no useful information so it is not plotted. It is tempting to ascribe the alignment of the stations along Vector I to contamination because the contaminated stations were plotted negative to the reference stations, but uncontaminated Stn 3 lies closer to the contaminated stations than the other refer-

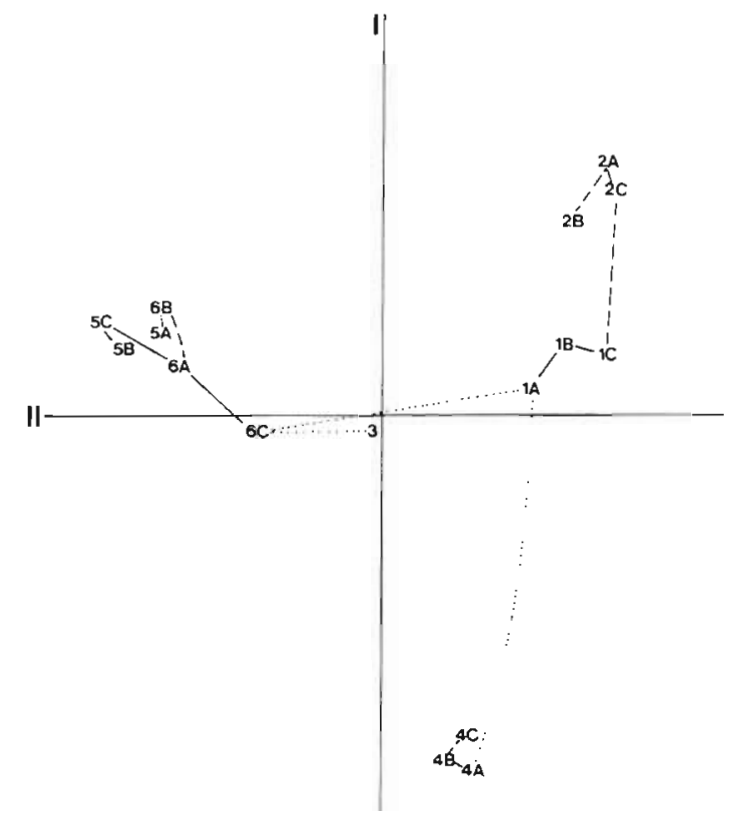

Fig. 12. Principal coordinate analysis of the cores using the Bray-Curtis index of similarity; $\mathrm{y}$ axis $=$ Vector $\mathrm{I}, \mathrm{x}$ axis $=$ Vector II. The MST is overlaid, dotted line indicates similarity of 35 to $50 \%$, dashed line 51 to $63 \%$ and unbroken line 64 to $73 \%$

ence stations so the results are equivocal. Also the minimum spanning tree does not suggest a split into 2 groups, contaminated and uncontaminated.

The plot for Vectors I and II for the 5th ordination carried out using the Bray-Curtis index of similarity is shown in Fig. 12. The results are similar to Gower's index, except there is even less suggestion of a contaminated and uncontaminated split. Vector III, which is not plotted, split off Core 5A as an outrider. This core has only a low percentage connection ( $37 \%$ ) with the other Ayr Bay cores according to the minimum spanning tree.

Fig. 13 shows the results for a reciprocal-averaging analysis of the data. The figure shows the sites plotted on Vectors I and II. The square roots of the eigenvalues gave a correlation between sites and species of 0.69 for Vector I, 0.67 for Vector II and 0.56 for Vector III, which is reasonable. The grouping produced for the cores was similar to the principal coordinates analyses except that the stations in north Ettrick Bay and south Ettrick Bay were grouped together by reciprocal averaging. Stn 3 is separated as an outrider and there is no suggestion of a fundamental split into contaminated and reference stations.

\section{Ecological cladistics}

Ordination and other phenetic techniques based on 'overall' or 'raw' similarity have been largely replaced 


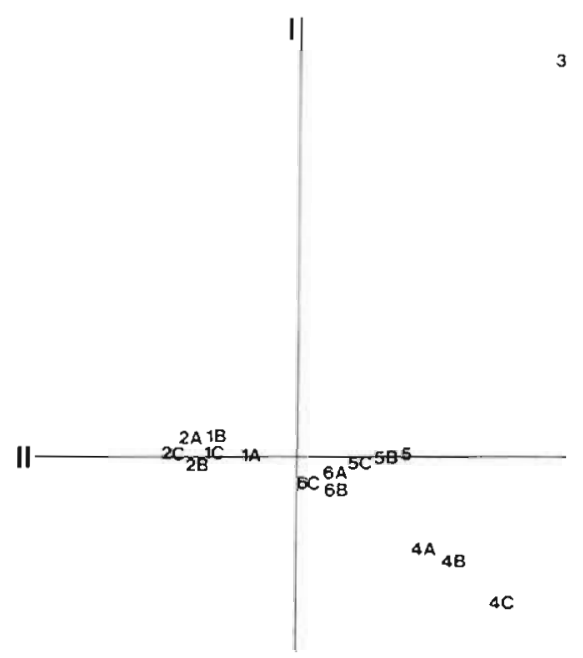

Fig. 13. Reciprocal averaging analysis of the cores; $y$ axis $=$ Vector $\mathrm{I}, \mathrm{x}$ axis $=$ Vector II

in systematics by cladistics. Cladistic analysis differs fundamentally from phenetics in that it involves the identification of monophyletic groups defined by the possession of one or more shared derived characters unique to that group. Lambshead \& Paterson (in press) argue the case for the application of cladistics to ecological analysis and demonstrate that the method has some significant advantages over phenetic analysis.

Sites can be grouped cladistically using species as characters in exactly the same manner as phenetics. The presence of a species is coded as a derived or homologous character while absence is coded as primitive. The outgroup is defined as a string of primitive characters, i.e. a sample with no species present. The implication of ecological cladistics is that species presence can be used as a homologous character. That is, if a species is present in 2 samples then its presence is assumed to be due the same key environmental factors influencing both samples. There exists the possibility of species being excluded from 2 or more samples for the same reasons, e.g. a homologous absence. Unfortunately, this cannot logically be used to construct the groupings since it could never be ascertained whether an absence is homologous or analogous except by inference from the groupings themselves.

A key point when using cladistics to group sites is that the species used as characters must have the potential for dispersion into all the sites were it not for the influence of the ecological parameters under test. This is really another example of the classic ecological criterion that like should be compared with like. This criterion is fulfilled in these samples since there is no reason to doubt that any of the nematode species have the capability for dispersion into any of the stations.
Cladistics offers 2 important advantages over phenetics. The first is greater explanatory power. The second is the ability to select between competing explanations by a logical criterion, parsimony, which involves no assumptions by the investigator about the results. Different phenetic algorithms commonly give different results when applied to the same data and there is no accepted biological way of choosing between them that does not involve circular reasoning.

The numerical cladistic program used in this analysis was a Camin-Sokal program called PHYLIP. This is not the most effective program but it has the merit of running on a modest minicomputer and appears to give adequately parsimonious cladograms when applied to ecological data (Lambshead \& Paterson in press).

Fig. 14 shows the most parsimonious cladogram for the relations between the cores. Dichotomy 1 divided the cores into 2 groups, a contaminated group and a reference group. Dichotomy 2 separated the reference cores spatially into Stn 1 and 2 (Ettrick Bay) and Stn 3 (Scalpsie Bay). Dichotomy 2' separated the contaminated cores spatially into Stn 4 (Irvine Bay) and Stn 5 and 6 (Ayr Bay) with the exception of Core $5 \mathrm{~A}$ which is an outrider being included with $\operatorname{Stn} 4$.

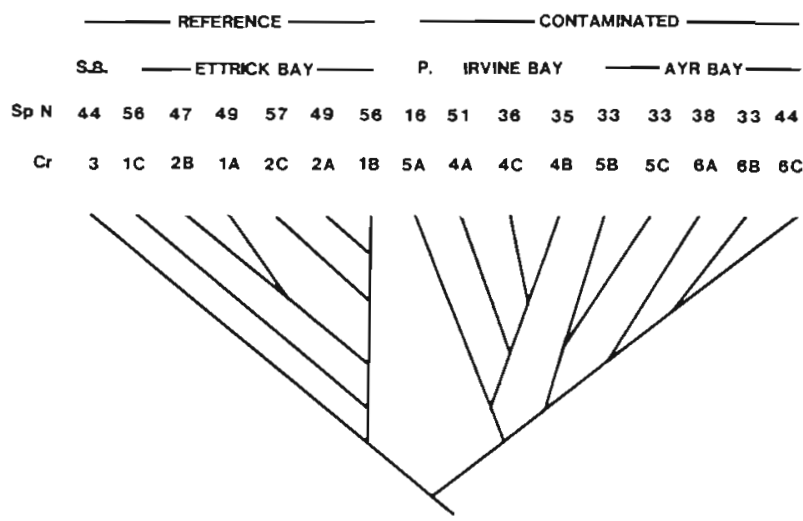

Fig. 14. Most parsimonious cladogram showing the relation between the cores. $\mathrm{Cr}=$ core, $\mathrm{Sp} \mathrm{N}=$ number of species in sample, $\mathrm{S} . \mathrm{B} .=$ Scalpsie Bay, $\mathrm{P} .=$ pipe (i.e. the core taken from the mouth of the effluent pipe)

\section{CONCLUSIONS}

The diversities, densities, feeding type ratios and $\mathrm{V}$ statistics for the nematode assemblages from the reference stations are consistent with the assumption that these assemblages are uncontaminated. In contrast, the $\mathrm{V}$ statistics, cladistic and, to some extent, multivariate analyses demonstrate that the nematode assemblages from the contaminated stations were detectably affected by non-catastrophic contamina- 
tion. In addition the effluent pipe in Ayr Bay had a localized effect detectable by feeding type ratios and nematode densities. This effect was most pronounced in Core $5 \mathrm{~A}$ which was taken from the terminus of the pipe.

These results suggest that nematode assemblages can be used to detect non-catastrophic levels of con- tamination provided suitably sensitive tests are applied. In this case a comparison with reference sites using neutral model or cladistic analysis was effective.

Acknowledgement. I thank Dr. H. M. Platt, who supervised this study, for both his critical advice and infectious enthusiasm for marine nematology

\section{APPENDIX}

Alphabetical list of nematode species encountered in the sixteen core-samples

\begin{tabular}{|c|c|c|c|c|c|c|c|c|c|c|c|c|c|c|c|c|c|}
\hline Species list & $\begin{array}{c}\text { Feeding } \\
\text { type }\end{array}$ & $1 \mathrm{~A}$ & $1 \mathrm{~B}$ & $1 \mathrm{C}$ & $2 \mathrm{~A}$ & $2 B$ & $2 \mathrm{C}$ & 3 & $4 \mathrm{~A}$ & $4 \mathrm{~B}$ & $4 \mathrm{C}$ & $5 A$ & $5 B$ & $5 \mathrm{C}$ & $6 \mathrm{~A}$ & $6 \mathrm{~B}$ & $6 \mathrm{C}$ \\
\hline 1. Actinonema celtica & $2 A$ & - & 1 & - & - & 1 & 1 & 23 & 2 & - & - & - & - & - & - & - & - \\
\hline 2. Adoncholaimus A & $2 B$ & - & - & 2 & - & - & - & - & - & - & - & - & - & - & - & - & - \\
\hline 3. Aegialoalaimus A & $1 \mathrm{~A}$ & - & - & 1 & - & - & - & - & - & - & - & - & - & - & 1 & - & - \\
\hline 4. Ammotheristus A & $1 B$ & - & 1 & - & - & - & - & - & - & - & 2 & - & - & - & - & - & - \\
\hline 5. Antomicron A & $1 A$ & - & - & - & - & - & - & - & - & 1 & - & - & - & - & - & - & - \\
\hline 6. Ascolaimus elongatus & $1 B$ & - & - & 3 & - & - & - & 8 & 6 & - & 5 & - & - & - & - & - & - \\
\hline 7. Bathylaimus A & $1 B$ & - & - & 1 & - & - & - & 2 & 1 & - & - & - & 2 & 1 & - & - & - \\
\hline 8. Calomicrolaimus acanthus & $2 A$ & 1 & 1 & 4 & 5 & 3 & 1 & - & 3 & 3 & 6 & - & - & - & 1 & 2 & 3 \\
\hline 9. Calomicrolaimus parahonestus & $2 A$ & 4 & 7 & 26 & 8 & 13 & 18 & 23 & 38 & 10 & 10 & 1 & 2 & 1 & 4 & 2 & 1 \\
\hline 10. Camacolaimus tardus & $2 A$ & - & - & - & - & - & - & - & - & - & - & - & - & - & - & - & 1 \\
\hline 11. Campylaimus A & $1 \mathrm{~A}$ & - & 2 & - & - & - & - & - & - & - & - & - & - & - & - & - & - \\
\hline 12. Chaetonema nemanni & $1 B$ & 2 & - & - & 1 & 1 & - & - & 43 & 4 & 8 & 2 & 1 & - & - & 1 & - \\
\hline 13. Chitwoodia tripapillata & $1 \mathrm{~A}$ & 1 & - & - & - & - & - & - & - & - & - & - & - & - & - & - & - \\
\hline 14. Chitwoodia warwicki & $1 A$ & 6 & 1 & 18 & 4 & 8 & 18 & 8 & 90 & 14 & 3 & 1 & 1 & - & 4 & - & 3 \\
\hline 15. Chromadoridae A & $2 A$ & - & - & - & - & - & - & - & - & - & - & - & 10 & 4 & 5 & 3 & 3 \\
\hline 16. Chromaspirinia inglisi & $2 A$ & 5 & 19 & 17 & 67 & 23 & 68 & 13 & - & - & - & - & - & - & - & - & - \\
\hline 17. Cobbia A & $1 B$ & 1 & 1 & - & - & 7 & 4 & - & - & - & - & - & - & - & - & - & - \\
\hline 18. Coninckia A & $1 \mathrm{~A}$ & - & - & - & 1 & - & - & 1 & - & - & - & - & - & - & - & - & - \\
\hline 19. Cyartonema elegans & $1 \mathrm{~A}$ & 2 & 4 & 5 & 2 & 2 & 2 & - & - & - & - & - & - & 1 & 2 & 2 & 3 \\
\hline 20. Cyartonema germanicum & $1 \mathrm{~A}$ & - & 5 & 4 & - & - & - & - & 16 & 5 & 2 & - & 1 & 1 & 1 & 2 & 4 \\
\hline 21. Cyartonema zosterae & $1 \mathrm{~A}$ & 4 & 6 & 18 & - & - & - & - & 4 & - & - & - & - & 1 & - & - & 1 \\
\hline 22. Cyatholaimid $A$ & $2 A$ & 1 & - & - & - & 3 & 3 & - & - & - & - & - & - & - & - & - & - \\
\hline 23. Daptonema invagiferoum & $1 B$ & 10 & 4 & 7 & - & 1 & 2 & 55 & 55 & 4 & 1 & 8 & 21 & 24 & 33 & 26 & 22 \\
\hline 24. Daptonema normandicus & $1 B$ & - & - & - & - & - & - & - & 8 & 1 & 1 & 1 & 19 & 13 & 9 & 1 & 1 \\
\hline 25. Daptonema A & $1 B$ & - & 1 & - & 2 & 1 & - & - & - & - & - & - & - & - & - & - & - \\
\hline 26. Daptonema B & $1 B$ & - & - & - & - & - & - & - & - & - & - & - & - & - & 2 & - & - \\
\hline 27. Daptonema C & $1 B$ & 8 & - & - & - & 10 & - & - & 16 & - & - & - & - & - & - & - & - \\
\hline 28. Daptonema D & $1 B$ & - & - & - & - & 3 & 1 & - & - & - & - & - & - & - & - & - & - \\
\hline 29. Daptonema E & $1 B$ & - & - & - & - & - & 1 & - & 1 & - & - & - & - & 1 & 1 & - & 5 \\
\hline 30. Daptonema $\mathrm{F}$ & $1 B$ & - & - & - & - & - & - & - & - & - & - & - & 2 & 1 & 5 & 5 & 8 \\
\hline 31. Dasynemella A & $1 \mathrm{~A}$ & - & - & - & 2 & 2 & - & 1 & 2 & - & - & - & - & 1 & - & - & 1 \\
\hline 32. Desmolaimus zeelandicus & $1 B$ & - & 4 & - & - & - & - & - & - & - & - & - & - & - & - & - & - \\
\hline 33. Dichromadora cucullata & $2 A$ & 1 & 8 & 2 & 11 & 7 & 9 & 19 & 19 & - & - & - & - & - & - & - & - \\
\hline 34. Dichromadora hyalocheile & $2 A$ & - & - & - & 4 & 7 & 2 & 52 & - & - & - & - & 3 & - & 1 & - & - \\
\hline 35. Dichromadora A & $2 A$ & 1 & - & 1 & - & - & - & - & - & - & - & - & - & - & - & - & - \\
\hline 36. Diplopeltula A & $1 \mathrm{~A}$ & 2 & 3 & 6 & 4 & 5 & 3 & - & 9 & - & - & - & - & 3 & 6 & 3 & 2 \\
\hline 37. Eleutherolaimus A & $1 B$ & - & - & 1 & - & - & 1 & 5 & 1 & - & - & - & - & - & - & - & - \\
\hline 38. Enoploides spiculohamatus & $2 B$ & - & - & - & - & - & 1 & 1 & 32 & 6 & 1 & 1 & - & - & 1 & - & - \\
\hline 39. Enoploides A & $2 B$ & - & - & - & - & - & - & - & 1 & - & - & - & - & - & - & - & - \\
\hline 40. Enoplolaimus propinquus & $2 B$ & 7 & 2 & 5 & - & - & - & 34 & 17 & 3 & 2 & 2 & 5 & 1 & 1 & 1 & 3 \\
\hline 41. Eubostrichus A & $1 \mathrm{~A}$ & 1 & 2 & 1 & - & - & 6 & - & - & - & - & - & - & - & - & - & - \\
\hline 42. Gammanema $\mathrm{A}$ & $2 B$ & 1 & 2 & 4 & 3 & 3 & - & - & 8 & - & 3 & - & 2 & 1 & 5 & 1 & 3 \\
\hline 43. Gonionchus longicaudatus & $1 B$ & - & 1 & 2 & 1 & 1 & 3 & 11 & - & - & - & - & - & - & - & - & 2 \\
\hline 44. Halalaimus capitulatus & $1 \mathrm{~A}$ & - & 2 & - & 2 & 1 & 1 & - & - & - & - & - & - & - & - & - & - \\
\hline 45. Leptolaimus ampullaceus & $1 \mathrm{~A}$ & - & - & 1 & 17 & 10 & 16 & 11 & 22 & - & - & - & - & - & - & - & - \\
\hline 46. Leptolaimus scotlandicus & $1 A$ & 11 & - & - & - & 10 & - & - & 245 & 102 & 76 & - & - & 3 & 1 & 1 & 2 \\
\hline 47. Leptonemella aphanothecae & $1 \mathrm{~A}$ & 56 & 73 & 189 & 82 & 33 & 116 & 28 & 14 & 2 & 3 & - & - & - & - & - & 1 \\
\hline 48. Metachromadora scotlandica & $2 A$ & - & 1 & - & 1 & 2 & 12 & - & - & - & - & - & - & - & - & - & - \\
\hline 49. Metachromadora suecica & $2 A$ & - & 2 & 3 & - & - & 1 & - & 151 & 74 & 67 & 6 & 2 & 2 & 1 & 3 & 2 \\
\hline 50. Metachromadora vivipara & $2 A$ & - & - & 1 & - & - & - & - & - & - & - & - & - & - & - & - & - \\
\hline 51. Metadesmolaimus aduncus & $1 B$ & 2 & 3 & 3 & 1 & 3 & 6 & - & 40 & 1 & - & - & 3 & 1 & 1 & - & 2 \\
\hline 52. Metadesmolaimus pandus & $1 B$ & 16 & 5 & 33 & - & 1 & 6 & 1 & 28 & 1 & 2 & 16 & 9 & 17 & 16 & 10 & 6 \\
\hline 53. Metadesmolaimus A & $1 B$ & - & - & - & - & - & - & - & 1 & - & - & - & - & - & - & - & - \\
\hline 54. Microlaimus acinaces & $2 \mathrm{~A}$ & 4 & 7 & 14 & 4 & 3 & 12 & 25 & 22 & 4 & 2 & - & 1 & 2 & 5 & 2 & 5 \\
\hline 55. Microlaimus macrocirculus & $2 A$ & 4 & 10 & 21 & 13 & 32 & 36 & - & - & - & - & - & - & - & - & - & - \\
\hline
\end{tabular}


Appendix. Continued

\begin{tabular}{|c|c|c|c|c|c|c|c|c|c|c|c|c|c|c|c|c|c|}
\hline Species list & $\begin{array}{l}\text { Feeding } \\
\text { type }\end{array}$ & $1 \mathrm{~A}$ & $1 \mathrm{~B}$ & $1 \mathrm{C}$ & $2 \mathrm{~A}$ & $2 \mathrm{~B}$ & $2 \mathrm{C}$ & 3 & $4 \mathrm{~A}$ & $4 \mathrm{~B}$ & $4 \mathrm{C}$ & $5 \mathrm{~A}$ & $5 B$ & $5 \mathrm{C}$ & $6 \mathrm{~A}$ & $6 \mathrm{~B}$ & $6 \mathrm{C}$ \\
\hline 56. Microlaimus monstrosus & $2 A$ & 1 & 3 & - & 1 & - & 1 & - & 21 & 8 & 2 & 1 & 1 & - & 1 & 1 & 2 \\
\hline 57. Microlaimus ostracion & $2 A$ & 1 & - & 1 & 4 & 2 & 9 & 11 & 3 & - & 1 & - & 3 & 4 & 3 & 2 & 8 \\
\hline 58. Microlaimus A & $2 A$ & - & 1 & - & 3 & - & 1 & - & - & - & - & - & - & - & - & - & - \\
\hline 59. Monhystera venusta & $1 A$ & - & - & - & 1 & - & 2 & - & 94 & 50 & 161 & - & 1 & - & - & - & 1 \\
\hline 60. Monoposthia mirabilis & $2 A$ & 19 & 11 & 21 & 14 & 5 & 8 & 2 & 46 & 13 & 18 & - & 4 & 1 & 3 & 8 & 6 \\
\hline 61. Nannolaimoides A & $2 A$ & 3 & 9 & 13 & 1 & - & 3 & - & 192 & 26 & 20 & - & 1 & 2 & 6 & 7 & 9 \\
\hline 62. Nannolaimus fusus & $1 A$ & - & 1 & 1 & 2 & - & - & - & - & - & - & - & - & 2 & 1 & - & - \\
\hline 63. Neochromadora paratecta & $2 A$ & 6 & 13 & 25 & 18 & 4 & 7 & 13 & - & - & 1 & - & 2 & 1 & - & 1 & 2 \\
\hline 64. Neochromadora tecta & $2 A$ & - & 1 & - & 2 & - & 5 & 438 & - & - & - & - & - & - & - & - & - \\
\hline 65. Neochromadora trichophora & $2 A$ & 84 & 56 & 90 & 14 & 22 & 12 & 230 & 397 & 102 & 47 & 4 & 32 & 23 & 35 & 14 & 61 \\
\hline 66. Neochromadora A & $2 A$ & - & - & - & - & - & - & - & 108 & 23 & 7 & - & - & - & - & - & - \\
\hline 67. Neotonchus boucheri & $2 A$ & - & - & - & - & - & 2 & 2 & 13 & 1 & 1 & - & - & - & - & 1 & - \\
\hline 68. Odontophora exharena & $2 A$ & 18 & 30 & 32 & 2 & - & - & - & - & - & - & -- & - & - & - & - & - \\
\hline 69. Odontophora rectangula & $2 \mathrm{~A}$ & 3 & - & 5 & - & - & - & - & 51 & 15 & 3 & - & - & - & - & - & 1 \\
\hline 70. Odontophoroides paramonhystera & $2 A$ & 3 & 1 & 2 & 2 & 2 & 1 & 68 & - & 7 & 6 & - & 3 & 4 & 2 & 2 & 2 \\
\hline 71. Oxystomina elongata & $1 \mathrm{~A}$ & - & - & - & 1 & - & - & - & - & - & - & - & - & - & - & - & - \\
\hline 72. Paracanthonchus thaumasius & $2 A$ & - & 2 & 1 & - & - & - & - & 44 & 16 & 13 & - & 2 & - & 1 & 1 & 1 \\
\hline 73. Paracyatholaimus occultus & $2 A$ & - & - & - & - & - & - & 12 & - & - & - & - & - & - & - & - & - \\
\hline 74. Paracyatholaimus pentodon & $2 A$ & 13 & 60 & 47 & - & - & 1 & - & 9 & 9 & 2 & - & 2 & - & 1 & - & - \\
\hline 75. Polysigma fuscum & $2 A$ & - & - & 2 & 1 & 8 & 3 & - & - & - & - & - & - & - & - & - & - \\
\hline 76. Pomponema debile & $2 A$ & 1 & 3 & 11 & 1 & 5 & 5 & 9 & - & 1 & - & - & - & - & 2 & - & 1 \\
\hline 77. Pomponema effilatum & $2 A$ & - & - & - & - & 3 & 2 & - & - & - & - & - & - & - & - & - & - \\
\hline 78. Pomponema sedecima & $2 A$ & - & 1 & - & - & - & 1 & - & 4 & - & - & - & - & - & - & - & - \\
\hline 79. Prochromadorella ditlevseni & $2 A$ & 64 & 62 & 100 & 21 & 8 & 24 & 8 & 193 & 36 & 14 & 1 & 11 & 8 & 24 & 9 & 15 \\
\hline 80. Pselionema A & $1 \mathrm{~A}$ & - & - & 1 & 1 & - & 4 & - & - & - & - & - & - & - & - & - & - \\
\hline 81. Pseudonchus A & $1 B$ & - & - & 1 & - & - & 1 & - & - & - & - & - & - & - & - & - & - \\
\hline 82. Rhabdocoma riemanni & $1 A$ & - & - & - & - & - & - & 4 & - & - & - & - & - & - & - & - & - \\
\hline 83. Rhabdodemania imer & $1 B$ & - & - & - & - & - & - & 9 & - & - & - & - & - & - & - & - & - \\
\hline 84. Rhynconema A & $1 A$ & 6 & 5 & 12 & - & - & - & 9 & - & - & - & - & 3 & 3 & 6 & 1 & 8 \\
\hline 85. Richtersia inaequalis & $1 B$ & - & - & - & 1 & - & - & - & 19 & - & - & - & - & - & - & - & 1 \\
\hline 86. Sabatieria longiseta & $1 B$ & - & - & 4 & - & - & - & - & - & - & - & - & - & - & - & - & - \\
\hline 87. Sabatieria longispinosa & $1 B$ & 24 & 18 & 15 & 4 & 10 & 6 & - & 12 & 2 & 1 & 1 & - & 11 & 9 & 5 & 13 \\
\hline 88. Sigmophoranema litorale & $2 A$ & - & - & - & - & - & - & 6 & - & - & - & - & - & - & - & - & - \\
\hline 89. Siphonolaimus ewensis & $2 B$ & - & - & - & - & - & - & 1 & 1 & - & - & - & - & - & - & - & - \\
\hline 90. Spiliphera hirsuta & $2 A$ & 18 & 47 & 69 & 3 & 3 & 11 & 43 & - & - & - & - & - & - & - & - & - \\
\hline 91. Spilophorella candida & $2 A$ & - & - & - & - & - & - & 30 & - & 5 & 5 & - & 3 & 3 & - & - & - \\
\hline 92. Spilophorella paradoxa & $2 A$ & 1 & - & - & - & - & - & 22 & - & - & - & - & - & - & - & - & - \\
\hline 93. Spirinia laevis & $1 A$ & - & 1 & 1 & - & 1 & - & - & - & 2 & - & - & - & - & 1 & - & - \\
\hline 94. Stephanolaimus elegans & $1 A$ & - & - & - & 6 & 6 & 5 & 2 & - & - & - & - & - & - & - & - & - \\
\hline 95. Stephanolaimus A & $1 A$ & - & - & - & 3 & - & 1 & - & - & - & - & - & - & - & - & - & - \\
\hline 96. Tarvaia angusta & $1 \mathrm{~A}$ & 1 & 1 & 1 & 1 & - & - & 1 & - & - & - & - & - & - & - & - & - \\
\hline 97. Terschellingia communis & $1 \mathrm{~A}$ & - & 2 & - & - & - & - & - & - & - & - & - & - & - & - & - & - \\
\hline 98. Terschellingia A & $1 \mathrm{~A}$ & - & 1 & - & - & - & - & - & - & - & - & - & - & - & - & - & - \\
\hline 99. Thalassoalaimus A & $1 \mathrm{~A}$ & - & - & - & - & - & 1 & - & - & - & - & - & - & - & - & - & - \\
\hline 100. Theristus bastiani & $1 \mathrm{~A}$ & - & 3 & 2 & - & - & - & - & - & - & - & - & - & - & - & - & - \\
\hline 101. Theristus curvatus & $1 B$ & 4 & 1 & 6 & - & - & - & - & - & - & - & - & - & 3 & - & - & 2 \\
\hline 102. Theristus fleveniis & $1 B$ & 1 & - & - & 3 & 2 & - & - & - & - & - & - & - & - & - & - & - \\
\hline 103. Theristus interstitialis & $1 B$ & - & - & - & - & - & - & - & - & - & - & - & 3 & - & & - & - \\
\hline 104. Theristus munnui & 18 & 62 & 26 & 79 & 104 & 121 & 76 & 34 & 104 & 24 & 73 & 2 & 5 & 15 & 17 & 9 & 35 \\
\hline 105. Theristus pertenuis & $1 B$ & - & - & - & - & - & - & - & 3 & - & - & - & - & - & - & - & - \\
\hline 106. Theristus A & $1 B$ & 1 & - & - & - & - & 1 & - & - & - & - & - & - & - & - & - & - \\
\hline 107. Theristus $\mathrm{B}$ & $1 B$ & - & - & - & - & - & - & - & - & - & - & - & 1 & - & - & 1 & 3 \\
\hline 108. Trefusia A & $1 \mathrm{~A}$ & 2 & - & - & 4 & 1 & 16 & - & - & - & - & - & - & - & - & - & - \\
\hline 109. Trichotheristus mirabilis & $1 B$ & 17 & 1 & 8 & 7 & 4 & 8 & 13 & 40 & 11 & 37 & 1 & 9 & 9 & 13 & 16 & 7 \\
\hline 110. Trileptium parisetum & $2 B$ & - & - & - & - & - & - & 1 & - & - & - & - & - & - & - & - & - \\
\hline 111. Viscosia cobbi & $2 B$ & 3 & 7 & 5 & 4 & 21 & 7 & 9 & 71 & 14 & 2 & - & - & - & - & 2 & 2 \\
\hline 112. Viscosia A & $2 B$ & 1 & 4 & 2 & - & 1 & 4 & - & 1 & - & - & - & - & - & - & - & - \\
\hline 113. Xyala riemanni & $A B$ & - & - & - & - & - & - & 117 & - & - & - & 2 & - & - & - & - & - \\
\hline Unidentified specimens & & 7 & 21 & 21 & 15 & 30 & 28 & 61 & 80 & 8 & 7 & 1 & 5 & 7 & 1 & 5 & 3 \\
\hline Totals & & 515 & 570 & 971 & 479 & 455 & 6061 & 14762 & 2405 & 608 & 616 & 51 & 175 & 175 & 232 & 152 & 269 \\
\hline
\end{tabular}

\section{LITERATURE CITED}

Admiralty Tide Tables, Vol 1 (1978). Published by the Hydrographer of the Navy, The Crown, U.K.

Boucher, G. (1980). Impact of Amoco Cadiz oil spill on inter- tidal and sublittoral meiofauna. Mar Pollut. Bull. 11: 95-101

Caswell, H. (1976). Community structure: a neutral model analysis. Ecol. Monogr. 46: 327-354

Coull, B. C., Palmer, M. A. (1984). Field experimentation in 
meiofaunal ecology. In: Heip, C. (ed.) Biology of meiofauna. Dr. W. Junk, Dordrecht, p. 1-19

Ewens, W. J. (1972). The sampling theory of selectively neutral alleles. Theoret. Populat. Biol. 3: 87-112

Ferris, V R., Ferris, J. M. (1979). Thread worms (Nematoda). In: Hart, C. W. Fuller, S. L. H. (ed.) Pollution ecology of estuarine invertebrates. Academic Press, London, p. 1-33

Giere, O. (1979). The impact of oil pollution on intertidal meiofauna. Field studies after the La Coruna-spill, May. 1976. Cah. Biol. mar. 20: 231-251

Halcrow, W., Mackay, D. W., Bogan, J. (1974). PCB levels in Clyde marine sediments and fauna. Mar. Pollut. Bull. 5: $134-136$

Halcrow, W., Mackay, D. W., Thornton, I. (1973). The distribution of trace metals and fauna in the Firth of Clyde in relation to the disposal of sewage sludge. J. mar. biol. Ass. U.K. 53: 721-739

Heip, C., Decraemer, W. (1974). The diversity of nematode communities in the southern North Sea. J. Mar. biol. Ass. U.K. 54: 251-255

Hopper, B. E., Myers, S. P. (1967). Population studies on benthic nematodes within a subtropical seagrass community. Mar. Biol. 1: 85-96

Jayasree, K. (1976). Free-living marine nematodes from polluted intertidal sand in Scotland. Ph.D. thesis, Aberdeen Univ.

Johnston, R., Adams, J. A., Dooley, H. D. (1974). Some observations on the hydrography, chemistry and plankton of the Firth of Clyde in relation to nitrate-rich effluents. In: (ed. anonymous) An assessment of present knowledge compiled by Members of the Clyde Study Group. NERC Publications Ser. C 11, England, p. 16-21

King, C. E. (1962). Some aspects of the ecology of psammolittoral nematodes in the north eastern Gulf of Mexico. Ecology 43: 515-523

Kito, K. (1984). Feeding types of free-living marine nematodes and their distribution as a means of analysing the nematode assemblages. Bull. Jap. Benthology 26: 23-30

Lambshead, P. J. D. (1984). The nematode/copepod ratio Some anomalous results from the Firth of Clyde. Mar. Pollut. Bull. 15: 256-259

Lambshead, P. J. D., Paterson, G. L. J. (in press). Ecological cladistics - an investigation of numerical cladistics as a method for analysing ecological data. J. nat. Hist.

Lambshead, P. J. D., Platt, H. M. (1985). Structural patterns of marine benthic assemblages and their relationship with empirical statistical models. In: Gibbs, P. E. (ed.) Nineteenth European marine biology symposium. Cambridge University press, Cambridge p. 371-380

Lambshead, P. J. D., Platt, H. M., Shaw, K. M. (1983). The detection of differences among assemblages of marine benthic species based on an assessment of dominance and diversity. J. nat. Hist. 17: 859-874

Lorenzen, S. (1981). Entwurf eines phylogenetischen Systems der freilebenden Nematoden. Veröff. Inst. Meeresforsch. Bremerhaven Suppl. 7: 1-472

Mackay, D. W., Halcrow, W., Thornton, I. (1972). Sludge dumping in the Firth of Clyde. Mar. Pollut. Bull. 3; 7-10

Mackay, D. W., Topping, G. (1970). Preliminary report on the effects of sludge disposal at sea. Effluent and Water Treatment Journal 7: 1-7

Mclntyre, A. D. (1977). Effects of pollution on inshore benthos. In: Coull, B. C. (ed.) Ecology of marine benthos. Univ. of South Carolina, Columbia, p. 301-318

McIntyre, A. D., Munro, A. L. S., Steele, J. H. (1970). Energy flow in a sand ecosystem. In: Steele, J. H. (ed.) Marine food chains. Oliver \& Boyd, Edinburgh, p. 19-31

McLachlan, A., Winter, P. E. D., Botha, I. (1977). Vertical and horizontal distribution of sub-littoral meiofauna in Algoa Bay, South Africa. Mar Biol. 40: 355-364

Morgans, J. F. C. (1956). Notes on the analysis of shallowwater soft substrata. J. Anim. Ecol. 25: 367-387

Platt, H. M. (1971). The ecology and taxonomy of freeliving marine nematodes from an intertidal sandflat in Strangford Lough. Ph.D. thesis, Queen's Univ. of Belfast

Platt, H. M. (1977a). Vertical and horizontal distribution of free-living marine nematodes from Strangford L.ough, Northern Ireland. Cah. Biol. mar. 18: 261-273

Platt, H. M. (1977b). Ecology of free-living marine nematodes from an intertidal sandflat in Strangford Lough, Northern Ireland. Estuar. coast. mar. Sci. 5: 685-693

Platt, H. M. (1984a). Classify worms and spot pollution. New Scient. 104: 28-29

Platt, H. M. (1984b). Planners and pollution: afloat on a sea of ignorance. New Scient. 104: 34-35

Platt, H. M., Lambshead, P. J. D. (1985). Neutral model analysis of patterns of marine benthic species diversity. Mar. Ecol. Prog. Ser. 24: 75-81

Platt, H. M., Shaw, K. M., Lambshead, P. J. D. (1984). Nematode species abundance patterns and their use in the detection of environmental perturbations. In: Heip, C. (ed.) Biology of meiofauna. Dr. W. Junk, Dordrecht, p. $59-66$

Platt, H. M., Warwick, R. M. (1980). The significance of freeliving marine nematodes to the littoral ecosystem. In: Price, J. H., Irvine, D. E. G., Farnham, W. F. (ed.) The shore environment, Vol. 2. Academic Press, London, New York, p. $729-759$

Platt, H. M., Warwick, R. M. (1983). Freeliving marine nematodes. Part 1. British enoplids. Kermack, D. M., Barnes, R. S. K. (ed.) Synopses of the British fauna (new series). Cambridge University Press, Cambridge

Raffaelli, D., Mason, C. F. (1981). Pollution monitoring with meiofauna, using the ratio of nematodes to copepods. Mar. Pollut. Bull. 12: 158-163

Shaw, K. M., Lambshead, P. J. D., Platt, H. M. (1983). Detection of pollution-induced disturbance in marine benthic assemblages with special reference to nematodes. Mar. Ecol. Prog. Ser. 11: 195-202

Tietjen, J. H. (1969). The ecology of shallow water meiofauna in two New England estuaries. Oecologia (Berl.) 2: 251-291

Tietjen, J. H. (1980). Population structure and species composition of the free-living nematodes inhabiting sands of the New York Bight Apex. Estuar. coast. mar. Sci. 10: $61-73$

Topping, G., McIntyre, A. D. (1972). Benthic observations on a sewage sludge dumping ground. Coun. Meet. int. Coun. Explor. Sea C.M.-ICES/E: 30

Warwick, R. M. (1971). Nematode associations in the Exe Estuary. J. mar. biol. Ass. U.K. 51: 439-454

Warwick, R. M., Price, R. (1979). Ecological and metabolic studies on free-living nematodes from an estuarine mudflat. Estuar. coast. mar. Sci. 9: 257-271

Wieser, W. (1953). Die Beziehung zwischen Mundhöhlengestalt, Ernährungsweise und Vorkommen bei freilebenden marinen Nematoden. Eine ökologisch-morphologische Studie. Ark. Zool. 4: 439-484

Wormald, A. P. (1976). Effects of a spill of marine diesel oil on the meiofauna of a sandy beach at Picnic Bay, Hong Kong. Envir. Pollut. 11: 117-130 